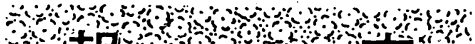

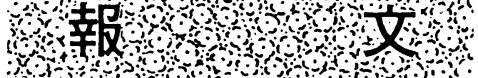 \\ 高速液体クロマトグラフィーによる食肉中の \\ 残留合成抗菌剤の分析
}

(平成 5 年 11 月 15 日受理)

$\begin{array}{ll}\text { 堀井昭三* } & \text { 宮川弘之* } \\ \text { 井草京子* } & \text { 伊藤 武* }\end{array}$

\section{Analysis of Residual Synthetic Antibacterials in Meat and Poultry Meat by High Performance Liquid Chromatography}

\author{
Shozo Horiı, Hiroyuki Miyakawa, Kyoko Igusa and Takeshi Itoh \\ (The Tokyo Metropolitan Research Laboratory of Public Health: 3-24-1, \\ Hyakunincho, Shinjuku-ku, Tokyo 169, Japan)
}

\begin{abstract}
A simple and sensitive HPLC method is described for quantitative determination of some synthetic antibacterials in animal tissues. The compounds are divided into two groups, $\mathrm{A}$ and B. Tissue samples are extracted with acetonitrile and then group A is purified on a silicagel cartridge and group B by hexane partition; no other clean-up procedure is needed. Recoveries of the antibacterials spiked in animal tissue were $64 \sim 99 \%$. The detection limits of quantitative determination by the proposed method were $0.01 \mathrm{ppm}$ for each antibacterial. The calibration curves for these compounds showed good linearity in the ranges of $0.5 \sim 50 \mathrm{ng}$ for carbadox, $1 \sim 100 \mathrm{ng}$ for thiamphenicol and furazolidone and 2 200 ng for other drugs. Many chicken samples (total 121) which were purchased from a poultry processing plant in Tokyo were analyzed by the proposed method. Decoquinate was detected in two samples of chicken muscle at levels of 0.02 and $0.03 \mathrm{ppm}$.
\end{abstract}

(Received November 15, 1993)

Key words: 高速液体クロマトグラフィー high performance liquid chromatography; 食肉 meat; 食鳥肉 poultry meat; 合成抗菌剂 synthetic antibacterials; 残留分析 residual analysis

食生活の向上と共に動物性食品への嗜好が高まり，畜 産物の供給量む年々増加しているが，生産者数は減少 し, 一生産者当たりの飼育頭羽数の増加は著しい"1).この ため, 家畜の疾病予防や治療及び生産効率確保を目的之 して各種薬㶡の使用は避けられない。使用したこれらの 薬剂が畜産物中に残留する可能性も否定できず，厚生省 は畜水産食品中の合成抗菌剂の分析法を通知してい $ろ^{21 \sim 5)}$. 平成 3 年 10 月の通知 によよれば，ニワトリの場 合, アンプロリウム (APL) は蛍光デンシトメーターを,

* 東宗都计衛牛研究所：テ169 東京都新宿区百人町 3-24-1
デコキネート $(\mathrm{DEQ})$ は蛍光分光光度計を，チアンフェ ニコール (TP)，オキソリン酸 $(\mathrm{OXA})$ 及びサルファ剂は 高速液体クロマトグラフ (HPLC) を用いて分析すること になっている. 平成 4 年 4 月からは食鳥検查制度む実施 され, 食鳥肉の安全性確保のために, 微生物学的検查と 併せて化学的方法に基づく残留抗菌性物質検查む重要視 されてきた。このため検查の迅速性は多数の検体を検査 する場合に欠かせない，著者らはこれまでにも簡易，迅 速でかつ高感度な分析法の検討61.7)を進めているが，今

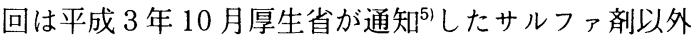
の検査対象合成抗菌剂にピリメタミン (PYR)，ナイカル 
Sample $20 \mathrm{~g}$

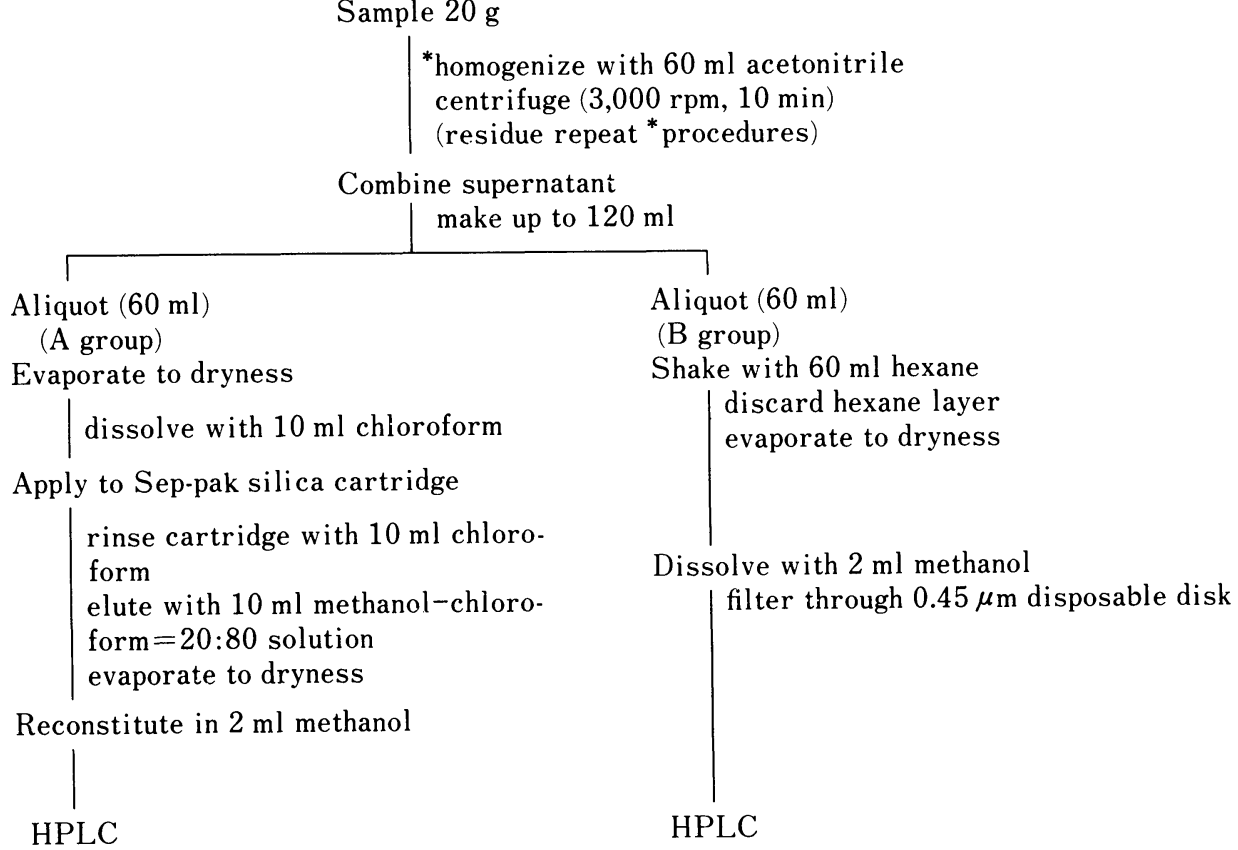

Scheme 1. Flow Diagram of Analytical Procedure

バジン (NCZ) を加え HPLC のみで分析する方法を鶏肉 の他, 豚肉と牛肉についても検討した。

\section{実験方法}

1. 試料

薬剂不含飼料で飼育したニワトリ，ブタ，ウシで，薬 棛を含まないことが判明している舀肉, 豚肉, 牛肉を添 加回収実験に, 食鳥処理場より収去した鷄肉及び市販の 豚肉, 牛肉を実態調查に供した。

2. 試 抗菌剂標準品は食品指定検査機関協議会より購入し た. APL, OXA，TP，フラゾリドン (FRZ) は水-アセトニ トリル $(1: 1)$ 溶液で $100 \mu \mathrm{g} / \mathrm{g}, \quad \mathrm{NCZ}$, カルバドックス (CDX) はアセトニトリルで $50 \mu \mathrm{g} / \mathrm{g}, \mathrm{PYR}$, クエン酸モ ランテル (MRT), ジフラゾン (DFZ) はメタノールで 100 $\mu \mathrm{g} / \mathrm{g}, \mathrm{DEQ}$ はクロロホルムで $100 \mu \mathrm{g} / \mathrm{g}$ 標準溶液を作製 し, 適宜メタノールで希釈した。アセトニトリルは HPLC 用，その他の溶媒と試薬は市販特級品を使用し た。シリカゲルカートリッジはSep-Pak シリカ (Millipore), 液ク口用前処理フィルターはクロマトディスク 13N C-133（クラボウ）を使用した.

3. 装

HPLC システム，ポンプ：LC-6AD (2 台)；UV 検出 器: SPD-6AV; 営光検出器: RF-550A; 制御部: SCL6B; 試料注入部：SIL6B; カラム恒温槽：CTO-6A; デー夕処 理装置：クロマトパック C-R 4 AX（以上(株)島津製作 所); 脱気装置: Shodex Degas KT-35 (昭和電工(株))
Table 1. Group of Synthetic Antibacterials

\begin{tabular}{ccl}
\hline \hline Tissue & Group & \multicolumn{1}{c}{ Compounds } \\
\hline Chicken & A & $\begin{array}{l}\text { Thiamphenicol, pyrimethamine } \\
\text { nicarbazin, decoquinate }\end{array}$ \\
& B & Amprolium, oxolinic acid \\
Swine & A & Thiamphenicol \\
& B & Carbadox, morantel citrate \\
& & furazolidone, difurazon \\
Bovine & A & oxolinic acid \\
& B & Oxiamphenicol \\
& Oxolinic acid \\
\hline
\end{tabular}

\section{4. 試験溶液の調製}

アセトニトリルとへキサンによる分配やシリカゲルカ ートリッジへの保持等を考慮し， Table 1 に示したとお り抗菌剤を A, B 2 群に分け, Scheme 1 に示した方法で 試験溶液の調製を行った。

\section{結果及び考察}

\section{1. 検查対象抗菌剤の選択}

検査対象抗菌剂は平成 3 年 10 月の厚生省通知 ${ }^{5}$ 及び 汎用性などを考慮して選択したが，当所ではサルファ斉 については日常検査において微生物学的検査を主に実施 しており，化学的検查を補完的に行い支障が無いため, 今回は検討しなかった．各抗菌剤は操作性や化学的性質 により Table 1 に示したグループに分けた。これらの抗 菌剤の分析方法については, 厚生省通知以外にも多くの 

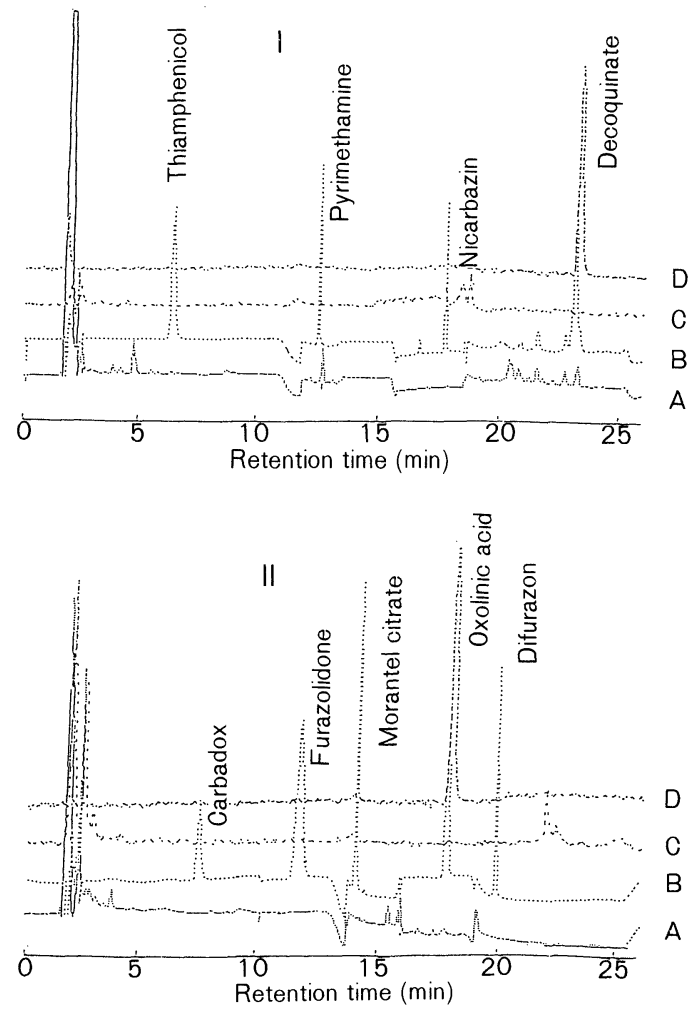

Fig. 1. Liquid chromatograms of chicken (I) and swine (II)

A (UV) and C (FL): drug free sample

$B$ (UV) and D (FL): synthetic antibacterials

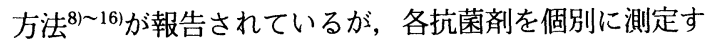
る方法 ${ }^{8)}$. 9) が多い，複数の抗菌剤の同時分析についての 報告屯標準品 ${ }^{10}$ のみか, 試料に添加した場合は, HPLC の分析条件は別 ${ }^{11)}$ 13) にっているあの，あるいは，サル ファ剂のみ ${ }^{14)}$, キノロン剂のみ ${ }^{15)}$, フラン剂のみ ${ }^{16)}$ な゙ のように同種類のものを対象にしたものが多い. 試料中 の各薬剂を含む同時分析法屯何報 ${ }^{17) ~ 19)}$ か報告されてい るが，これらの報告は今回の著者らの方法より低い検出 限界であり, 更に, 試料の前処理が一段階のものは見当 らない.

日常分析法として全薬剤を同一のクリーンアップ法, 及び HPLC 分析条件で操作できれば良いが，今回のよ うに分析対象薬剤の化学的性質が異なる場合は, 困難で ある. そのため, 各抗菌剤を Table 1 に示したとおり,

$\mathrm{A}, \mathrm{B}$ 両グループに分けて分析することとした. これらの 抗菌剂は汎用性や平成 3 年 10 月の厚生省通知等を考慮 したものである.

クリーンアップ操作を可能な限り少なくすることを心 掛け, まず, Sep-pak シリカに保持され, メタノールーク ロロホルム $(1: 9 \mathrm{v} / \mathrm{v})$ 混液 $10 \mathrm{ml}$ で溶出される抗菌剤
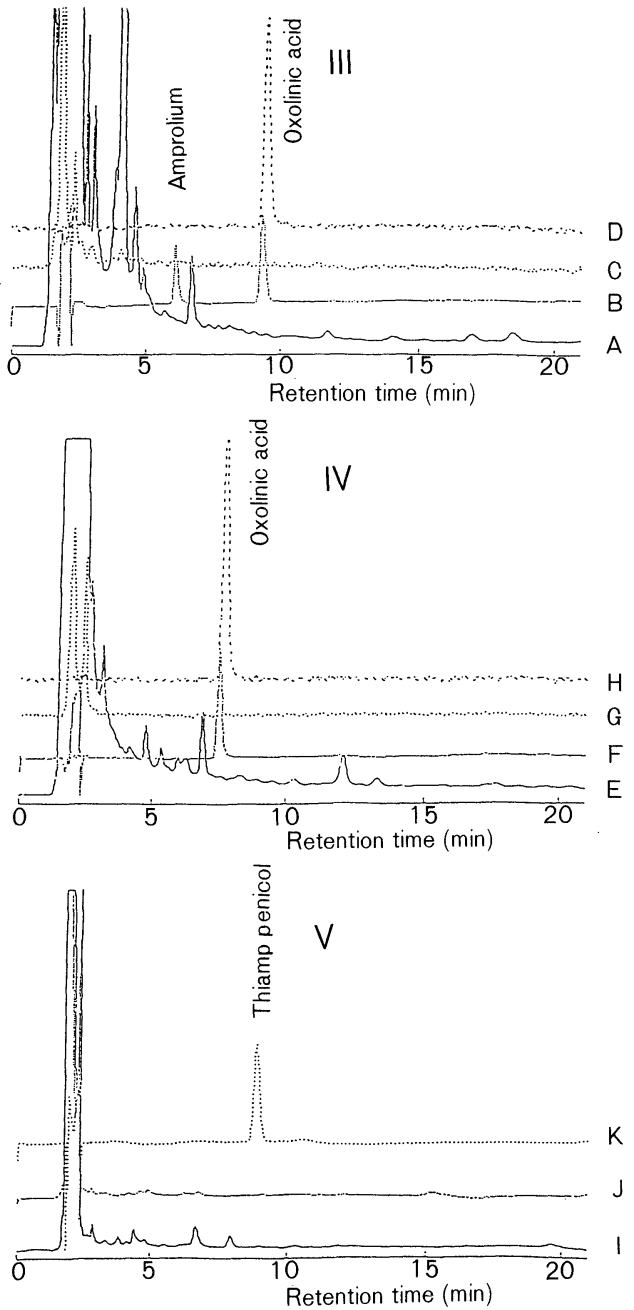

Fig. 2. Liquid chromatograms of chicken (III), bovine (IV), swine (V, I) and bovine (V, J)

A, E, I and J (UV) \& C and G (FL): drug free sample, $B, F$ and $K(U V) \& D$ and $F$ (FL): synthetic antibacterials

を A グループとした. 残りの抗菌剂は, 厚生省通知に準 拠し, ヘキサンによる脱脂 (1 回) のみを行い, B グルー プとした. 両グループともクリーンアップ操作は一段階 のみである (Scheme 1). ブ夕に使用される CDX は A, $\mathrm{B}$ どちらのグループに入れても分析できるが，よりクリ ーンアップ操作が簡単な B グループとした.

\section{HPLC 测定条件}

OXA と DEQ はUV 検出のほか蛍光検出も可能なの で, UV 検出器と蛍光検出器を直列に接続した. Fig. 1 のI に鶏肉 A 群, Fig. 2 の III に鶏肉 B 群を, Fig. 1 の II に豚肉 B 群, Fig. 2 の V に豚肉 A 群, Fig. 2 の IV, V に牛肉 B，A 群の HPLC クロマトグラムを示した。 な 
Table 2. HPLC Operating Conditions

\begin{tabular}{|c|c|c|c|}
\hline Application & Mode & Mobile phase & Detection \\
\hline Swine A \& bovine $\mathrm{A}$ & Isocratic & $\mathrm{I}-\mathrm{II}=85: 15$ & $\mathrm{UV}: 230 \mathrm{~nm}$ \\
\hline Chicken A & Gradient & $\begin{array}{r}\text { II }(\%) \\
0 \sim 7 \min , 15(\%) \\
7 \sim 12 \min , 30(\%) \\
12 \sim 22 \min , 70(\%) \\
22 \sim 55 \min , 15(\%)\end{array}$ & $\begin{array}{r}\text { UV: } 0 \sim 15.5 \min , 230 \mathrm{~nm} \\
15.5 \sim 18.5 \min , 340 \mathrm{~nm} \\
18.5 \sim 54 \min , 254 \mathrm{~nm} \\
54 \sim 55 \min , 230 \mathrm{~nm} \\
\text { FL: } E x .326 \mathrm{~nm}, E m .384 \mathrm{~nm}\end{array}$ \\
\hline Swine B & Gradient & $\begin{array}{r}\text { II }(\%) \\
0 \sim 9 \min , 12(\%) \\
9 \sim 15 \min , 25(\%) \\
15 \sim 22 \min , 45(\%) \\
22 \sim 55 \min , 12(\%)\end{array}$ & 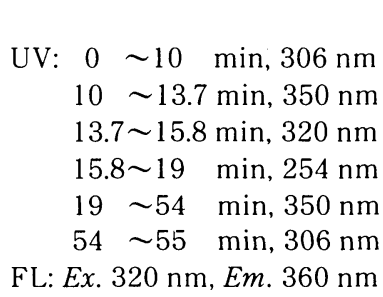 \\
\hline Chicken B & Isocratic & $\begin{array}{l}(\mathrm{I}+10 \mathrm{~m} M \text { sodium } \\
\quad \text { heptanesulfonate })-\mathrm{II} \\
\quad=80: 20\end{array}$ & $\begin{array}{l}\text { UV: } 254 \mathrm{~nm} \\
\text { FL: Ex. } 320 \mathrm{~nm}, E m .360 \mathrm{~nm}\end{array}$ \\
\hline Bovine B & Isocratic & $\mathrm{I}-\mathrm{II}=80: 20$ & $\begin{array}{l}\mathrm{UV}: 254 \mathrm{~nm} \\
\text { FL: Ex. } 320 \mathrm{~nm}, E m .360 \mathrm{~nm}\end{array}$ \\
\hline
\end{tabular}

Column: L-column ODS, $4.6 \phi \times 150 \mathrm{~mm}$ (Chemicals Inspection \& Testing Institute); Column oven: $40^{\circ} \mathrm{C}$; Flow rate: $1 \mathrm{ml} / \mathrm{min}$; Sensitivity: 0.01 aufs

I: $0.025 \%$ Phosphoric acid; II: Acetonitrile

お，HPLC 分析条件を Table 2 に示した.

APL は移動相にイオンペア一試薬を加えなければ, ODS カラムに保持されないため, 鶏肉の B グループの 移動相にはイオンペアー試薬として，ヘプタンスルフォ ン酸ナトリウムを $10 \mathrm{~m} M$ 加えたが, 鶏肉の B グループ 以外の移動相には，すべて $0.025 \%$ リン酸とアセトニト リルからなる混合液のみを使用した。移動相としてのリ ン酸は酢酸に比べ，UV 低波長領域に吸収を持たないた めUV 検出器の感度を上げても良好な HPLCクロマト グラムが得られ，より高感度な分析が可能となった。

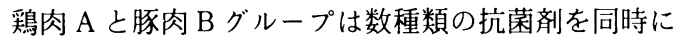
分離することから，グラジェント（Table 2) を行った. Scheme 1 に示したような簡易なクリーンアップにもか かわらず, 鶏肉, 豚肉, 牛肉の各グループとも, マトリ ックスの影響を受けずに定量可能であった。 Table 2 で 示した条件で, グラジェントを 1 昼夜連続しても, 保持 時間に変動は認められなかった（誤差 士2\%以内）. 各 薬剂ともそれぞれの吸収極大が異なるので, 波長プログ ラミングにより最適波長で測定した。

\section{3. 添加回収実験}

抗菌剂が含ま机ていない細切した肉 $10 \mathrm{~g}$ に各抗菌剂 $2 \mu \mathrm{g}$ 及び $10 \mu \mathrm{g}$ (OAX は半量) を添加し, 本法に従って 操作して回収率を求め Table 3 に示した。

鵎肉では, NCZ の回収率が最も低く $0.2 \mu \mathrm{g} / \mathrm{g}$ 添加で $65.6 \%, 1 \mu \mathrm{g} / \mathrm{g}$ 添加で $74.5 \%$ であった。他の薬剤はい
ずれも $0.2 \mu \mathrm{g} / \mathrm{g}$ 添加で $75 \%$ 以上の回収率を示した。特 にTPは 90\%,OXA は95\% 以上と良好であった。豚肉 では, CDX の回収率が最も低く, TP と OXA が高い回 収率を示した。牛肉では, TPと OXA を対象としたが, 鶏肉, 豚肉同様良好な結果が得られた。

\section{4. 検量線の作成と検出限界}

各抗菌剂とも UV 検出器で測定した場合, 原点を通る 直線性の高い検量線が得られた $(r=0.999)$. CDX は 0.5 50 ng, FRZ と TPは2 200 ng, その他の抗菌剤 はいずれも $1 \sim 100 \mathrm{ng}$ の間に，直線性が見られた。（す べての抗菌剤に 100 倍にわたる直線性が見られたこと から，定量範用の広いことが示唆された）なお，検出限 界はいずれの抗菌剤も $0.01 \mu \mathrm{g} / \mathrm{g}$ であった.

\section{5. 試料への適用}

本法を食鳥処理場より収去した鶏肉 121 検体に適用 したところ，2 検体より DEQ を検出（0.02 と $0.03 \mu \mathrm{g} /$ g）した，市販の豚肉，牛肉各 20 検体からはいずれの薬 剂も検出されなかった. DEQを検出した検体について は, 更に, 厚生省通知法源により追試験を行った結果，ほ ぼ同様の值が出た。今回の方法で分析した後の試料を， 移動相にカルシウムを加え，DEQ が蛍光強度を増す木 下 $^{18)}$ の方法に基じて測定したところ，DEQ と同一保持 時間を有するピークは標準品と京様に蛍光強度を增すこ と（約 3 倍）が確認された。

分析対象に加えなかったが，スルファメラジン，スル 
Table 3. Recovery of Synthetic Antibacterials from Animal Tissues

\begin{tabular}{|c|c|c|c|}
\hline Tissue & Compound & $\begin{array}{l}\text { Added } \\
(\mu \mathrm{g} / \mathrm{g})\end{array}$ & $\begin{array}{c}\text { Rec. } \pm \text { S.D. } \\
(\%)\end{array}$ \\
\hline \multirow[t]{12}{*}{ Chicken } & \multirow[t]{2}{*}{ Thiamphenicol } & 0.2 & $90.5 \pm 5.4$ \\
\hline & & 1.0 & $91.0 \pm 1.8$ \\
\hline & \multirow[t]{2}{*}{ Pyrimethamine } & 0.2 & $75.3 \pm 4.1$ \\
\hline & & 1.0 & $90.3 \pm 4.0$ \\
\hline & \multirow[t]{2}{*}{ Nicarbazin } & 0.2 & $65.6 \pm 5.1$ \\
\hline & & 1.0 & $74.5 \pm 2.1$ \\
\hline & \multirow[t]{2}{*}{ Decoquinate } & 0.2 & $85.7 \pm 4.2$ \\
\hline & & 1.0 & $84.5 \pm 2.7$ \\
\hline & \multirow[t]{2}{*}{ Amprolium } & 0.2 & $75.6 \pm 3.1$ \\
\hline & & 1.0 & $95.3 \pm 7.3$ \\
\hline & \multirow[t]{2}{*}{ Oxolinic acid } & 0.1 & $96.3 \pm 2.3$ \\
\hline & & 0.5 & $98.2 \pm 2.6$ \\
\hline \multirow[t]{12}{*}{ Swine } & \multirow[t]{2}{*}{ Thiamphenicol } & 0.2 & $94.5 \pm 5.6$ \\
\hline & & 1.0 & $94.0 \pm 3.5$ \\
\hline & \multirow[t]{2}{*}{ Carbadox } & 0.2 & $63.6 \pm 4.8$ \\
\hline & & 1.0 & $82.8 \pm 3.2$ \\
\hline & \multirow[t]{2}{*}{ Furazolidone } & 0.2 & $84.0 \pm 3.1$ \\
\hline & & 1.0 & $89.4 \pm 1.0$ \\
\hline & \multirow[t]{2}{*}{ Difurazon } & 0.2 & $86.9 \pm 4.7$ \\
\hline & & 1.0 & $84.6 \pm 2.7$ \\
\hline & \multirow[t]{2}{*}{ Morantel citrate } & 0.2 & $88.9 \pm 3.6$ \\
\hline & & 1.0 & $94.8 \pm 3.8$ \\
\hline & \multirow[t]{2}{*}{ Oxolinic acid } & 0.1 & $92.5 \pm 4.0$ \\
\hline & & 0.5 & $95.8 \pm 4.1$ \\
\hline \multirow[t]{4}{*}{ Bovine } & \multirow[t]{2}{*}{ Thiamphenicol } & 0.2 & $91.1 \pm 4.7$ \\
\hline & & 1.0 & $92.3 \pm 3.8$ \\
\hline & \multirow[t]{2}{*}{ Oxolinic acid } & 0.1 & $87.2 \pm 2.6$ \\
\hline & & 0.5 & $98.9 \pm 0.7$ \\
\hline
\end{tabular}

Based on 5 determinations at each concentration.

ファジミジン, スルファモノメトキシン, スルファジメ トキシン，スルファキノキサリンは食肉中に残留すれば A, B グループともに検出される可能性はある. しかし, HPLC クロマトグラム上前述 5 種類のサルファ剂と同 一保持時間を有する物質は存在しなかった。

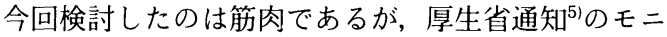
タリング対象組織である腎藏や肝臟についても今後検討 する予定である.

謝辞

試料の収集にあたられた東京都食品環境指導センター の皆様に深謝いたします。

文献

1）畜産統計 1992 年版, 農林水産省経済局統計情報部

2) 厚生省通知 環乳第 40 号 (1977).

3) 同上環乳第 34 号 (1979).

4) 同上衛乳第 105 号 (1990).

5) 同上衛乳第 94 号 (1991).

6) Horii, S., Momma, C., Miyahara, K., Maruyama, T., Matsumoto, M.: J. Assoc. Off. Anal. Chem. 73, 990 992 (1990).

7) Horii, S.: J. Liquid Chromatogr. 17, 213 221 (1994).

8）山本雄三, 橋口玲子, 荒木桂子, 串間奉文：食衛誌：32, 444 447 (1991)

9) Coleman, M. D., Edwards, G., Mihaly, G. W.: J. Chromatogr. 308, 363 369 (1984).

10) Ahuja, S. ed.: "Chromatography of Pharmaceuticals, ACS Symposium Series 512" p. 54 66 (1992), American Chemical Society, Washington, DC.

11）堀 義宏: 食衛誌. 24, 447 453 (1983).

12) 永田知子, 佐伯政信：同上 29, 13 20 (1988).

13）村山三徳, 内山貞夫, 斎藤行生：同上 $32,155 \sim 160$ (1991).

14) Bui, L. V.: J. Assoc. Off. Anal. Chem. Int. 76, 966 975 (1993).

15) Horie, M., Saito, K., Hoshino, Y., Nose, N., Mochizuki, E., Nakazawa, H.: J. Chromatogr. 402, 301 308 (1987).

16) Rupp, H. S., Munns, R. K., Long, A. R.: J. Assoc. Off. Anal. Chem. Int. 76, 1,235 1,239 (1993).

17）堀江正一, 星野庸二, 能勢憲英, 岩崎久夫, 中澤裕之：衛 生化学 31, 371 376 (1985).

18）山本 優, 大内格之, 富沢政, 菊地由生子, 高杉信男: 札幌市衛研年報. 16, 80 87 (1988).

19) Nagata, T., Saeki, M.: J. Liquid Chromatogr. 14, 2,551 2,561 (1991).

20）木下光明：飼料研究報告, 16, 112 123 (1991). 